\title{
Comparison of Accuracy in Cutting Dental Profiles Between Differential Methods Approach Upward with a Lower Approach to Making Straight Gear Wheels
}

\author{
Ganda Agustian, Yufrizal and Irzal \\ Jurusan Teknik Mesin, Fakultas Teknik, Universitas Negeri Padang, Indonesia
}

\section{Article Info}

Article history:

Received July $02^{\text {th }}, 2018$

Revised August 19 ${ }^{\text {th }}, 2018$

Accepted November $19^{\text {th }}, 2018$

\section{Keywords:}

Dental Profile

Differential Method

Accuracy Comparison

Odd

Tooth Thickness

\begin{abstract}
In the world of gear use industry is undeniable, every machine in the industrial world uses a component, namely gears to move rotating power. For this reason, in making gears the precision of the gear profile must be considered. The purpose of this study is to compare the accuracy of cutting the dental profile between the approach differential method and the approach to the bottom. This research is experimental research. Based on the results of data analysis about the comparison of the precision of cutting dental profiles between the approach differential methods and the approach to the bottom, the upward approach is more appropriate in terms of thickness and number of teeth. The number of samples used in the study of 12 gears consisting of 6 gears was carried out with the approach differential method, and 6 gears were carried out by the differential approach method. Each sample is measured in thickness and the number of teeth in a straight gear. After measuring the data, it is processed using the t-test formula to see the significant difference in the accuracy of the dental profile. Based on the results of the t-test analysis that has been carried out there are differences in the gears produced. The approach to differential approach to getting better gear results.
\end{abstract}

\section{Corresponding Author:}

Ganda Agustian,

Jurusan Teknik Mesin, Fakultas Teknik, Universitas Negeri Padang

Jln. Prof. Dr Hamka Air Tawar, Padang (25131), Sumatera Barat, Indonesia

Email: agustiangnda@gmail.com

\section{INTRODUCTION}

In the world of gear use industry is undeniable, every machine in the industrial world uses a component, namely gears to move rotating power. The role of gear in vehicles and the industrial world is very important in connecting or continuing the power rotation that results from kinetic energy processes to mechanical energy [1]. In its use, there are several types of gears which include the bevel gear, worm gear and straight gear (spur gear) [2]. Straight gears are used to move the rotary movement between the shafts [3]. For this reason, in making gears the precision of the gear profile must be considered.

Based on the results of observations made at the Mechanical Engineering Production Workshop in Padang State University, many of the students experienced difficulties and were not careful in making gears such as the number and shape of dental profiles were not appropriate, and the thickness of teeth was not evenly distributed. Especially in the manufacture of gears in an odd number and lots by using the differential method of approaching upward divisions and downward approaches. The differential method is a method of division in making dental profiles, differential methods can be done by means of an upward approach and a downward approach with the help of intermediary gears [4]. Differential methods are used when other methods of division cannot be used and are used when making dental profiles of straight gears in odd and many numbers [2].

For this reason, the researchers wanted to vary the intermediate gears used in each straight gear specimen, the upward differential method and the lower approach with ST 37 steel material. Straight gears were made using a milling machine. A milling machine is a cutting machine that can be used for various types of operations such as the operation of flat objects and surfaces that have irregular shapes, gears and bolt heads, boring, reaming [4]. This study aims to determine the shape of the gear profile with a differential and 
downward approach as well as to find out the more appropriate differential methods in making gear profiles in terms of thickness and number of straight gear profiles.

\section{MATERIAL DAN METHOD}

The specimen material used in this study is low carbon steel $(0.17 \%$ C) Steel ST 37 is one of the most widely used types of carbon steel with dimensions of $60 \mathrm{~mm}$ in diameter and $15 \mathrm{~mm}$ in thickness [5]. The tool used for conducting experiments is the Horizontal Freis Machine with a rotating speed of $200 \mathrm{rpm}$. In making gears there are two manufacturing systems, namely the module system and pitch diameter system [2], and in this case, the researcher uses a module system, so the type of knife used is the module knife type.

Table 1. Module knife number based on a number of teeth [2].

\begin{tabular}{cc}
\hline Milling knife number & For intermediate toothed gears \\
\hline 1 & $12-13$ gear \\
2 & $14-16$ gear \\
3 & $17-20$ gear \\
4 & $21-25$ gear \\
5 & $26-34$ gear \\
6 & $35-54$ gear \\
7 & $55-134$ gear \\
8 & 135 -gear steam (rack) \\
\hline
\end{tabular}

As table 1, this study uses a knife module 1 number knife 6 . Knife number 6 is used because this study is the number of dental profiles ( $\mathrm{Z}$ ) based on the design formula a is 53 teeth. By using the knife module the system module is used. The module system is one of the calculation systems used in determining the size/size of a gear that is planned to be made [2]. A tool for measuring the thickness of a specimen's dental profile, namely the gear wheel. Sigma this gear specimens as many as 12 specimens, 6 specimens using the bottom approach differential method and 6 more specimens using the approach differential approach method. Each specimen has the same size with different parameters. Each specimen was cut twice by reaching the feeding depth, each tooth specimen measured the thickness of the tooth profile as much as the number of dental profiles obtained then searched for the average thickness of the tooth profile.

The method used in this study is experimental research, which is the method used to test by adding several variations of treatment [6] so that the results will be obtained from the accuracy of dental profiles on straight gears. The variables carried out in this study are dependent variables and independent variables. The dependent variable is the variable that is affected. The dependent variable in this study is the accuracy of dental profiles. The independent variable is the variable that affects. The independent variable in this study is the approach differential method and the bottom approach. Data retrieval is done by examining the material by measuring the thickness of the tooth using a gear. As Figure 1 shows the gear parts, in this case, the researcher focused on the number of teeth and the thickness of the teeth. This study compared the accuracy of the gear profile between the differential methods approach and the downward approach in terms of thickness and number of gear gears, while for parts of the gear as a whole, namely:

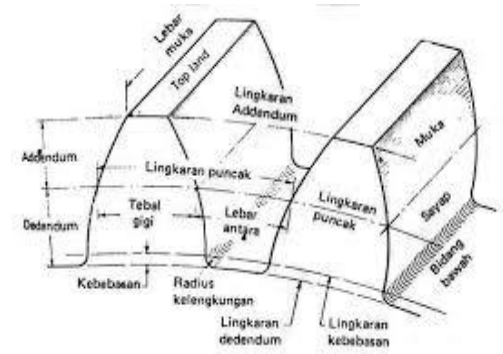

Figure 1. Parts of the Gear Wheel [7]

Figure 1 shows parts of a straight gear, straight gears having parts such as tooth thickness, tooth head, tooth head diameter, etc. The thickness of the teeth has a major influence on the smooth relationship between gears. The implementation method starts from (1) the design of the gear wheel; (2) material measurement; (3) cutting material; (4) formation of prospective specimens; (5) formation of test specimens; (6) experimental process; and lastly done (7) thickness measurement of tooth profile. Data analysis techniques are as follows: 
a. Calculate gear planningDt $=\mathrm{z} \times \mathrm{m}$

$$
\begin{aligned}
& \mathrm{Dk}=\mathrm{Dt} \times 2 . \mathrm{m} \\
& \mathrm{Hg}=2,25 \times \mathrm{m} \\
& \mathrm{Ha}=1 \times \mathrm{m} \\
& \mathrm{Hi}=1,25 \times \mathrm{m} \\
& \mathrm{Tg}=1,5708 \mathrm{~m} \\
& \mathrm{P}=\mathrm{II} \times \mathrm{m} \\
& \mathrm{Dr}=\mathrm{Dt}-2 . \mathrm{Hg}
\end{aligned}
$$

b. Standard deviation formula

$$
\mathrm{SDx} 1=\sqrt{\frac{\sum\left(\mathrm{X}_{\mathrm{i}}-\tilde{\mathrm{x}}\right)^{2}}{n-1}}
$$

c. Analyze significant levels

$$
t=\frac{\bar{x}_{1}-\bar{x}_{2}}{\sqrt{\frac{S D_{1}}{n_{1-1}}+\frac{S D_{2}}{n_{2-1}}}}
$$

The t-test analysis technique is used to find a significant level of comparison of the precision of the dental profile between the approach differential method and the downward differential approach method. The significant level can be determined by comparing the results of the formula with table $t$. If the value in table $t$ is greater than the calculated value of the test obtained then the level is said to be insignificant, and vice versa if the value of $t$ table is smaller than $t$ count the test results then the level is said to be significant.

Table 2. A significant level of table $\mathrm{t}[9]$

\begin{tabular}{lccccccc}
\hline \multicolumn{1}{c}{ d.f. } & \multicolumn{7}{c}{ Level of Significance } \\
\hline two sides & $20 \%$ & $10 \%$ & $5 \%$ & $2 \%$ & $1 \%$ & $0,2 \%$ & $0,1 \%$ \\
\hline one side & $10 \%$ & $5 \%$ & $2,5 \%$ & $1 \%$ & $0,5 \%$ & $0,1 \%$ & $0,05 \%$ \\
1 & 3,078 & 6,314 & 12,706 & 31,821 & 63,657 & 318,309 & 636,619 \\
2 & 1,886 & 2,920 & 4,303 & 6,965 & 9,925 & 22,327 & 31,599 \\
3 & 1,638 & 2,353 & 3,182 & 4,541 & 5,841 & 10,215 & 12,924 \\
4 & 1,533 & 2,132 & 2,776 & 3,747 & 4,604 & 7,173 & 8,610 \\
5 & 1,476 & 2,015 & 2,571 & 3,365 & 4,032 & 5,893 & 6,869 \\
6 & 1,440 & 1,943 & 2,447 & 3,143 & 3,707 & 5,208 & 5,959 \\
7 & 1,415 & 1,895 & 2,365 & 2,998 & 3,499 & 4,785 & 5,408 \\
8 & 1,397 & 1,860 & 2,306 & 2,896 & 3,355 & 4,501 & 5,041 \\
9 & 1,383 & 1,833 & 2,262 & 2,821 & 3,250 & 4,297 & 4,781
\end{tabular}

In table 2 the significant level to be used is the level of $5 \%$ assuming the level 10 so the table is 2.228. To find $t$ count used formula $\mathrm{c}$. The results of the analysist count will be compared with $\mathrm{t}$ table. 


\section{RESULTS AND DISCUSSION}

The making of gears has been carried out using a horizontal milling machine using module 1 no 6 knives based on table 1, figure 2 and figure 3 shows the test results.

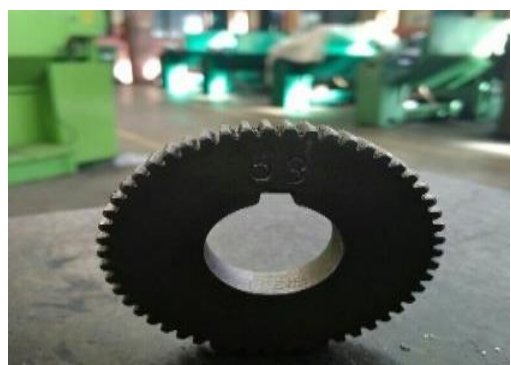

Fig. 2. Results of Making Gears

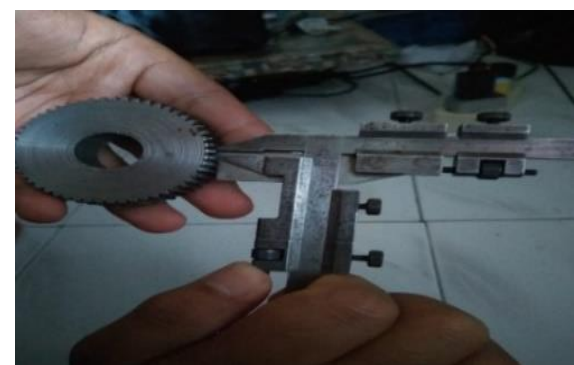

Fig. 3. Gear measurement

Figure 2 shows straight gear specimens that have been made with a milling machine, tooth profile cutters were made twice using a module knife 1 . Based on the formula a number of teeth to be obtained $(\mathrm{Z})$ is 53 tooth profiles and $1.5708 \mathrm{~mm}$ tooth thickness, the thickness of teeth obtained must be evenly distributed from the first tooth to the last tooth. Furthermore, the specimen is ready to be measured using the gear wheel as shown in Figure 3. Measurements were made specifically for the gear part, namely the thickness of the teeth. In addition to the thickness of the teeth, the number of dental profiles was also calculated for each gear specimen. The results can be seen in table 2 below:

Table 3. Measurement Data

\begin{tabular}{|c|c|c|c|c|c|c|c|c|c|}
\hline \multicolumn{6}{|c|}{ Downward Approach } & \multicolumn{4}{|c|}{ Upward Approach } \\
\hline \multirow{2}{*}{ Sample } & \multirow{2}{*}{ Z } & \multirow{2}{*}{$\mathrm{Tg}$} & \multicolumn{2}{|c|}{$\begin{array}{c}\text { Gear } \\
\text { Intermediary }\end{array}$} & \multirow{2}{*}{ Sampel } & \multirow{2}{*}{$\mathrm{Z}$} & \multirow{2}{*}{$\mathrm{Tg}$} & \multicolumn{2}{|c|}{ Gear Intermediary } \\
\hline & & & $\mathrm{Z3}$ & $\mathrm{Z} 4$ & & & & $\mathrm{Z} 3$ & $\mathrm{Z} 4$ \\
\hline 1 & 53 & 1.57 & 30 & 40 & 1 & 53 & 1.57 & 50 & \\
\hline 2 & 53 & 1.78 & 40 & 30 & 2 & 53 & 1.57 & 60 & \\
\hline 3 & 53 & 1.90 & 80 & 25 & 3 & 53 & 1.48 & 70 & \\
\hline 4 & 56 & 1.42 & 55 & 25 & 4 & 53 & 1.51 & 70 & \\
\hline 5 & 57 & 1.40 & 30 & 40 & 5 & 53 & 1.63 & 70 & \\
\hline 6 & 53 & 1.50 & 40 & 30 & 6 & 53 & 1.54 & 80 & \\
\hline
\end{tabular}

Table 2 is measurement data which is raw data before processing. After that, the data is moved to table 2 by changing it using the symbol " 1 " and the symbol " 0 ". The symbol " 1 " is given if the measurement data for each gear specimen that has been made is in accordance with the design in formula a, and is given the symbol " 0 " if the measurement results of each specimen do not match the design as in the formula a.

Table 4. Test Result Data

\begin{tabular}{cccccccc}
\hline \multirow{2}{*}{ Sample } & \multicolumn{3}{c}{ Downward Approach $\left(\mathrm{x}_{1}\right)$} & Sample & \multicolumn{3}{c}{ Upward Approach $\left(\mathrm{x}_{2}\right)$} \\
\hline & $\mathrm{Z}$ & $\mathrm{Tg}$ & Total & & $\mathrm{Z}$ & $\mathrm{Tg}$ & Total \\
1 & 1 & 1 & 2 & 1 & 1 & 1 & 2 \\
2 & 1 & 0 & 1 & 2 & 1 & 1 & 2 \\
3 & 1 & 0 & 1 & 3 & 1 & 0 & 1 \\
4 & 0 & 0 & 0 & 4 & 1 & 0 & 1 \\
5 & 0 & 0 & 0 & 5 & 1 & 0 & 1 \\
6 & 1 & 0 & 1 & 6 & 1 & 0 & 8 \\
\hline
\end{tabular}


In table 3 it is used to make it easier to do the test with t table analysis. In table 3 the results of the bottom gear differential gear making from the six samples obtained four gear samples that match the number of teeth based on the design of the formula a, for tooth thickness only one gear that is thick according to the design. As for the approach to the sixth sample for the number of teeth according to the design of the formula a and for tooth thickness only two gears are thick according to the design. As previous research based on the testing table shows differences occur in the thickness of the teeth with the rounding up approach technique that is one thick tooth that is not suitable from the five samples and with rounding down approach, there are two thick teeth that are not suitable. The upward approach obtains more samples that are standard because the process uses only one intermediate gear. As for the differential method, the lower approach uses two intermediate gears.

Table 5. Average Test Results of Straight Gear Wheel Profile

\begin{tabular}{ccc}
\hline Sample & X1 & X2 \\
\hline 1 & 2 & 2 \\
2 & 1 & 2 \\
3 & 1 & 1 \\
4 & 0 & 1 \\
5 & 0 & 1 \\
6 & 1 & 1 \\
\hline Average & 0.833 & 1.3 \\
\hline
\end{tabular}

In table 5 above, it can be seen the average accuracy of the dental profile of each specimen in the approach differential method and the downward approach. Furthermore, the average data is analyzed by the standard deviation of each approach to the differential method used as in formula $b$. The standard deviation of the differential method approach down (SDx1) is 0.752 and the standard deviation of the approach up (SDx2) is 0.518 . The standard deviation of the two approaches (SDx1 and SDx2) is analyzed into formula c to be analyzed t count, and the results of the analysis of t count are 1.144.

Based on the analysis of the data from the results of the study, it is known that the influence of the use of differential methods approaches up and down in the manufacture of straight gears which have a large number has an effect, but not too significant [8]. This is due to the fact that the t-test analysis found that the value of $t$ arithmetic is 0.144 after that compared to the $t$ table in table 2 of 2.228 , which shows that the $t$ count is smaller than $t$ table. The use of the upward differential approach method is more effective [10] because in the differential method the upward approach only uses one intermediate gear. For the differential method, the lower approach uses two intermediate gears so that in this case the approximation of the lower gear profile is less effective as in the previous study stated that the downward approach was less effective in making differential straight gears.

\section{CONCLUSION}

To achieve the objective of the research, that is to know the comparison of the accuracy of straight gear profiles between the differential methods of the lower approach and the upward approach, carried out by the experimental research method, namely the process of making gears on ST 37 steel specimens in horizontal milling machines. Based on the results of the research that has been done using the Sigma Roda Gigi tool, it is found that the price of the precision of the dental profile with the upward differential method is better than the differential approach of the bottom approach but not too significant based on table 2, proven in table 3 . upwards is greater ie 1.3 while the approach is down 0.833 . Therefore, in the process of making a straight gear with a differential method, it is better to use the differential approach to the top method to get the precision of the dental profile according to the design.

\section{REFERENCES}

[1] Marsis, P., Analisa Perancangan Roda Gigi Lurus Menggunakan Mesin Konvensional. Vol 7(2). 2013

[2] Yufrizal A. Teori dan Praktek Pembuatan Roda Gigi dengan Mesin Frais. UPT Pusat Media Pendidikan : FPTK IKIP Padang. 1990

Journal homepage: http://teknomekanik.ppj.unp.ac.id

DOI: https://doi.org/10.24036/tm.v2i2.1672 
[3] Hafli, T., Prilaku Kegagalan Roda Gigi Lurus Akibat Beban Fatik dan Impak. Sekolah Pasca Sarjana Universitas Sumatera Utara. 2006.

[4] Ansyori, A., Pengaruh Kecepatan Potong dan Makan terhadap Umur Pahat Pada Pemesinan Freis Paduan Magnesium. Vol.6(1). 2015.

[5] Erizon, N., Ardiyansyah, M.I., Jasman., \& Yufrizal. Effect of Cooling Media on Steel Hardness ST 37 of Conventional Lathe Process. Jurnal Teknomekanik. 1(1): 6-11. 2018.

[6] Sugiyono. Metode Penelitian Kuantitatif, Kualitatif, dan R\&D. Bandung: Alfabeta. 2017.

[7] Sudjana., Metode Statistik. Tarsito Bandung. 1973.

[8] SudjiMunadi. PengukuranRoda Gigi. DirjendiktiDepdiknas: P2LPTK Jakarta. 1998.

[9] Ramadan, G., Perbedaan Ketepatan Tebal dan Jumlah Gigi Dalam Pembuatan Roda Gigi Lurus Dengan Menandai dan Tanpa Menandai Menggunakan Metoda Pembagian Profil Gigi Differensial”. Skripsi Fakultas Teknik Universitas Negeri Padang. 2014.

[10] Afdal, H., Perbandingan Ketepatan Hasil Pembagian Menggunakan (Differensial Indexing Method) dengan Pendekatan Pemotongan Keatas dan Kebawah dalam Pembuatam Roga Gigi Lurus. Vol.1 (1), 2015 . 